\begin{tabular}{|l|l|}
\hline JURNAL ABDI MASYA & $\begin{array}{l}\text { Volume } 1 \text { Nomor } 1 \\
\text { November 2020 } \\
\text { pp 35-40 } \\
\text { Website: } \text { https://jurnal.sttw.ac.id/index.php/abma/about }\end{array}$ \\
\hline
\end{tabular}

\title{
PENERAPAN MESIN POTONG RUMPUT PAKAN SAPI SISTEM INDEPENDENT 4 BLADE DI UKM JUMANTONO
}

\section{APPLICATED COW FOOD GRADE CUTING MACHINE SYSTEM INDEPENDENT 4 BLADE IN JUMANTONO UKM}

\author{
Joko Yunianto Prihatin ${ }^{1 *}$, Suhartoyo ${ }^{2)}$, Karminto Ka $^{3)}$ \\ ${ }^{1), 2), 3)}$ Prodi Teknik Mesin, Sekolah Tinggi Teknologi Warga Surakarta, Surakarta, Indonesia \\ *Email: jokoyp.atw@gmail.com
}

\begin{abstract}
ABSTRAK
UKM ternak sapi yang dipimpin oleh bapak Suharji merupakan salah satu potensi pengusaha ternak di kabupaten Karanganyar desa Jumantono pada khususnya. Permasalahan utama adalah dalam upaya memenuhi ketersediaan pakan hasil potongan rumput yang berkualitas dan melimpah sulit diperoleh, sehingga banyak bahan sisa dan menurunnya kesehatan sapi tersebut. Terdapat sisa pakan rumput gajah 0.6 pikul atau $24 \%$ yang relatif banyak dan terbuang tidak dimakan oleh ternak. Metode pengabdian masyarakat ini bertujuan utama pembuatan mesin perajang rumput pakan ternak sistem pisau 4 blade horizontal. Kegiatan tersebut disertai dengan analisa permasalahan, perumusan solusi dan evaluasi hasil secara berkala. Hasil dari kegiatan pengabdian masyarakat ini adalah sebuah mesin peranjang rumput pakan ternak sapi berukuran 1200:800:1000 mm berpenggerak mesin bensin 5,5 pk mampu mencapai kapasitas produksi 600 kg/jam. Mesin perajang ini mampu meningkatkan kualitas perajangan rumput pakan ternak sapi dari $70 \mathrm{~kg} / \mathrm{jam}$ menjadi $600 \mathrm{~kg} / \mathrm{jam}$ dengan ukuran relatif homogen $90 \%$.
\end{abstract}

Kata Kunci : homogen, kapasitas perajang, rumput pakan ternak.

\section{Submit : 19 September 2020, Accepted: 1 Oktober 2020 Published: 24 November 2020}

\section{PENDAHULUAN}

Karanganyar merupakan kabupaten di Jawa Tengah yang berbatasan dengan kabupaten Sukoharjo, Sragen, Surakarta dan Wonogiri. Jumantono merupakan kecamatan dikabupaten Karanganyar pada sisi selatan yang berbatasan langsung dengan kabupaten Wonogiri. Dari segi pertanian kecamatan Jumantono merupakan daerah yang tanah pertaniannya lumayan subur dibandingkan dengan daerah lain seperti kecamatan Jumapolo, Tasikmadu yang daerahnya tandus bila pada musim kemarau. Wilayah Jumantono terdapat waduk yang sebagai pengairan sawah yaitu waduk Lalung yang menjadi sumber utama air pertanian. 


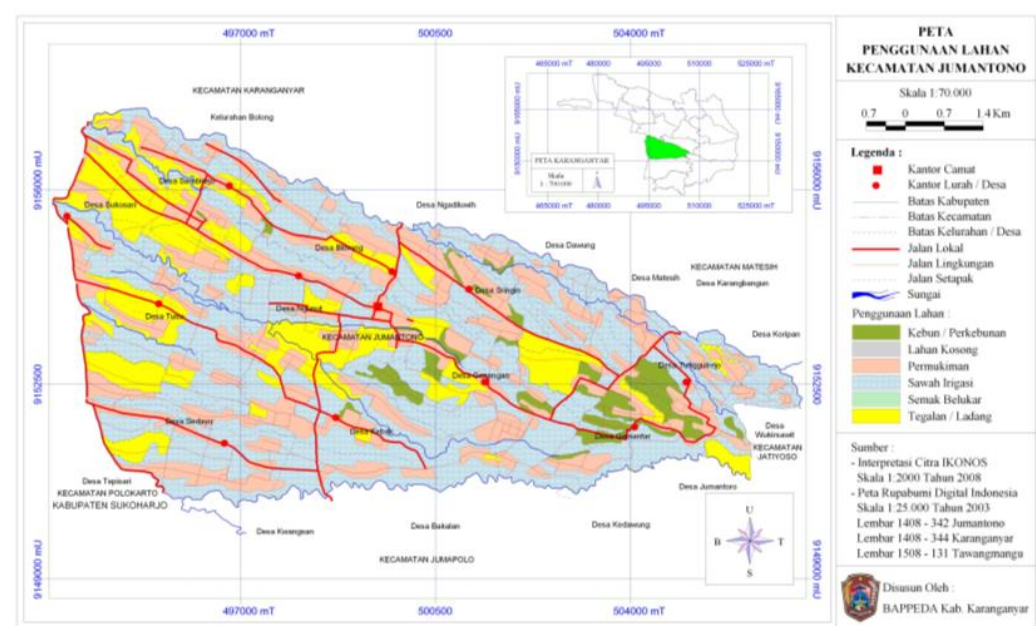

Gambar 1. Peta wilayah kabupaten karanganyar kecamatan jumantono

Mayoritas penduduk di jumantono bermata pencaharian utama beternak sapi. Didaerah desa sedayu dihuni oleh $50 \mathrm{KK}$, dimana setiap KK beternak sapi antara 3-5 ekor sapi pada ukm sapi, sehingga mencapai 235 sapi Dengan prosentase $85 \%$ beternak sapi lokal, $10 \%$ sapi metal, serta 5\% sapi perah. Menurut Suharji (pemilik ukm ternak sapi), bahwa antara makanan tambahan ampas tahu dan katul dengan rumput gajah dilihat dari tingkat kegemukan dan tingkat kwalitas gizi baik tersebut lebih cepat dengan pemberian makan rumput gajah atau batang pohon jagung. Daftar kebutuhan pakan ternak sesuai dijelaskan pada tabel dibawah ini :

Tabel 1. Pemberian rumput dan makanan tambahan

\begin{tabular}{cccccc}
\hline No & Makanan utama & Satuan & Pemakaian & Pemberian pakan & Sisa pakan \\
\hline 1 & Rumput Gajah & 2.5 pikul & 1 hari & 3-5 ekor sapi & 0,6 pikul \\
2 & Makanan Tambahan & 3 ember B & 1 hari & 3-5 ekor sapi & 0.1 ember B \\
\hline
\end{tabular}

S.L. Mujiyanti [1], pembuatan pakan lengkap yang dilakukan secara berkelompok dapat menghasilkan harga pakan yang lebih efisien karena efisiensi waktu pengadaan pakan dan dalam pengadaan bahan pakan limbah jagung sebagai bahan pokok pakan lengkap. Permasalahan utama petani sapi tersebut adalah upaya memenuhi ketersediaan hasil potongan pakan rumput yang berkualitas dan melimpah sulit diperoleh, sehingga banyak bahan sisa dan menurunnya kesehatan sapi tersebut. Berdasarkan tabel diatas menjelaskan bahwa terdapat sisa pakan rumput gajah 0.6 pikul atau $24 \%$ yang relatif banyak dan terbuang tidak dimakan oleh ternak. Kapasitas produksi yang dihasilkan hanya $76 \mathrm{~kg} / \mathrm{jam}$ sesuai kondisi dijelaskan pada gambar dibawah ini. 


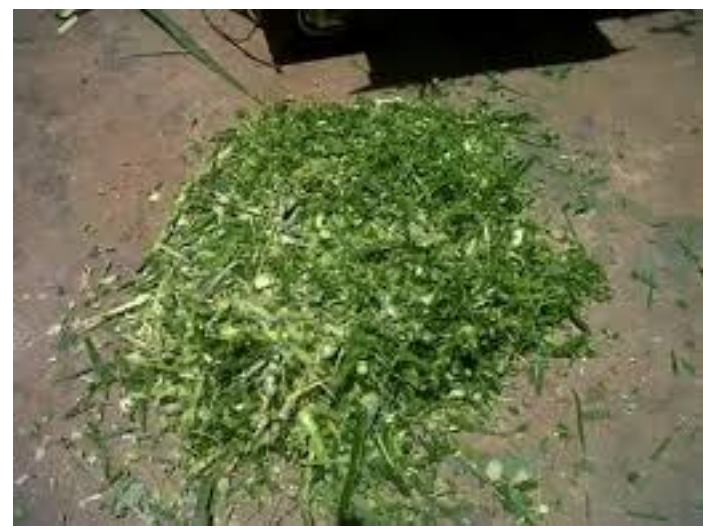

Gambar 2. Hasil potongan rumput pakan ternak yang kurang optimal

B.H. Priyambodo [2], proses perajangan secara konvensional juga menghasilkan ukuran rajangan pakan yang kurang homogen. Berdasarkan peralatan yang dipakai pada ukm ternak sapi tersebut masih relatif sederhana hanya mengandalkan pisau dan sabit, sehingga berdampak kepada kurang optimal kecepatan dan keseragaman hasil potongan rumput pakan ternak tersebut.

Berdasarkan latar belakang dan permasalahan diatas, sehingga kegiatan pengabdian masyarakat ini bertujuan untuk membuat mesin perajang rumput pakan ternak sapi sistem 4 blade horizontal. Mesin tersebut diharapkan bisa diterapkan untuk meningkatkan kapasitas kebutuhan pakan ternak pada ukm ternak sapi di Jumantono yang dipimpin oleh bapak Suharji.

\section{METODE}

Kegiatan pengabdian ini dilaksanakan di ukm ternak sapi di kecamatan Jumantono kabupaten Karanganyar Jawa Tengah. Kegiatan tersebut dilaksanakan oleh tim Sekolah Tinggi Teknologi warga Surakarta beserta pengelola ukm ternak sapi yang dipimpin oleh bapak Suharji pada bulan september tahun 2019. Ukm ternak sapi tersebut terletak di desa Sedayu kecamatan Jumantono kabupaten Karanganyar Jawa Tengah.

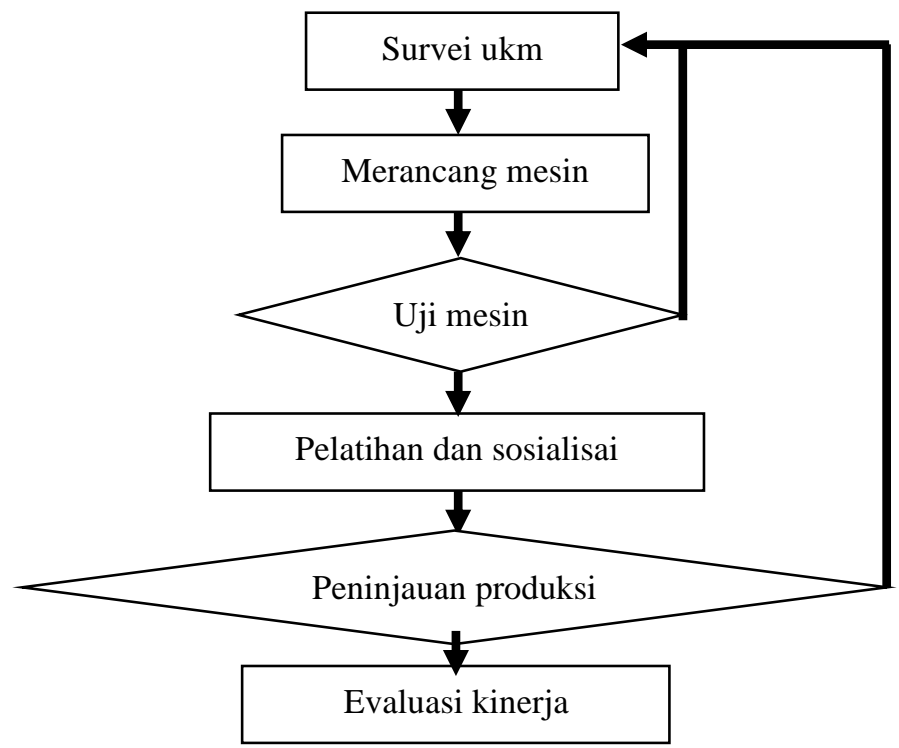

Gambar 3. Diagram alir pengabdian mesin perajang pakan ternak 4 blade 
Metode pelaksanaan pengabdian tersebut dapat dijelaskan dalam bentuk diagram alir seperti pada gambar 3 yang terdiri dari beberapa kegiatan, diantaranya adalah :

1. Melakukan survei awal sebagai langkah need assesment perangkat teknologi tepat guna yang dibutuhkan masyarakat beserta analisis situasinya dan studi pustaka termasuk penelusuran sejarah teknologi. Proses pencacahan makanan ternak yang selama ini menggunakan sabit, sehingga banyaknya sisa makanan sapi yang tidak habis, terutama rumput gajah, pohon jagung dan rumput lainnya (bagian batang bawah yang keras) dan penyediaan makanan alternatif di musim kemarau. Pencacah dengan sabit tidak efisien, yaitu lama dan hasilnya kurang baik atau masih terlalu panjang/tidak seragam.

2. Merancang dan pembuatan mesin perajang pakan ternak tersebut. Spesifikasi mesin pencacah makanan ternak ini terdiri dari kerangka dan sistem pisau. Daya engine $5,5 \mathrm{pk}$ bensin dengan putaran motor $1450 \mathrm{Rpm}$ ditransmisikan ke sistem pisau 4 blade horisontal sehingga mampu merajang dengan konstan dan stabil. Sistem kerangka menggunakan besi hollow 4x4x0.5 sehingga kekuatan tekan dan getaran yang ditimbulkan bisa stabil.

3. Melakukan uji coba hasil kegiatan baik di laboratorium maupun di lapangan tempat ukm ternak sapi. Hasil perajangan menggunakan sabit dibandingkan dengan hasil perajangan menggunakan sistem pisau 4 blade ini. Analisa hasil dititikberatkan kepada keseragaman ukuran dan kecepatan serta panjang hasilnya.

4. Mengadakan layanan informasi pengoperasian atau penggunaan teknologi tepat guna terhadap pengelola ukm ternak sapi tersebut secara berkala. Pada kegiatan ini bertujuan untuk mengetahui tingkat daya fungsi mesin ini terhadap perbandingan hasil perbandingan perajangan menggunakan sabit.

5. Mengadakan pelatihan dan sosialisasi pendayagunaan mesin tersebut kepada masyarakat sasaran. Serta memberikan konsultasi perawatan dan pemeliharaan mesin tersebut. Pihak pengelola ataupun dari anggota ukm yang mengoperasikannya diharapkan dapat tumbuh rasa memiliki dan merawat mesin ini. Sehingga permasalahan ataupun kebingungan dapat diatasi dengan segera.

6. Mengadakan peninjauan secara berkala di lapangan dalam penerapan teknologi tepat guna mesin perajang pakan ternak tersebut selama produksi berlangsung. Hasil perajangan antara penggunaan sabit dengan mesin ini dapat dilihat secara langsung perbandingannya.

Pelaksanaan kegiatan pengabdian ini tidak terlepas dari sudut pandang tinjauan pustaka beberapa penulis sebelumnya, diantaranya adalah :

H.Purwono [3], rancang bangun mesin perajang rumput jerami mencapai kapasitas produksi $500 \mathrm{~kg} / \mathrm{jam}$ dengan putaran mesin diesel dijaga dibawah 2000rpm.

I.Widdakso [4], rancang bangun mesin pencacah rumput gajah dengan pisau lengkung mampu mencapai kapasitas produksi $110 \mathrm{~kg} / \mathrm{jam}$.

T.W Prasojo [5], perancangan ulang mesin pencacah rumput dengan metode reverse engineering tersebut mampu mencacah rumput dengan jumlah $100 \mathrm{~kg}$ dalam waktu 10,73 menit menghabiskan bahan bakar sebanyak 0,74 liter. Hasil cacahan rerata menghasilkan panjang $0.5 \mathrm{~cm}$ yang homogen $98 \%$.

\section{HASIL DAN PEMBAHASAN}

Hasil kegiatan pengabdian ini terdiri dari wujud mesin perajang pakan ternak dan analisa hasil kualitas perajangan. Desain dan hasil mesin yang dicapai dapat dijelaskan pada gambar dibawah ini. 

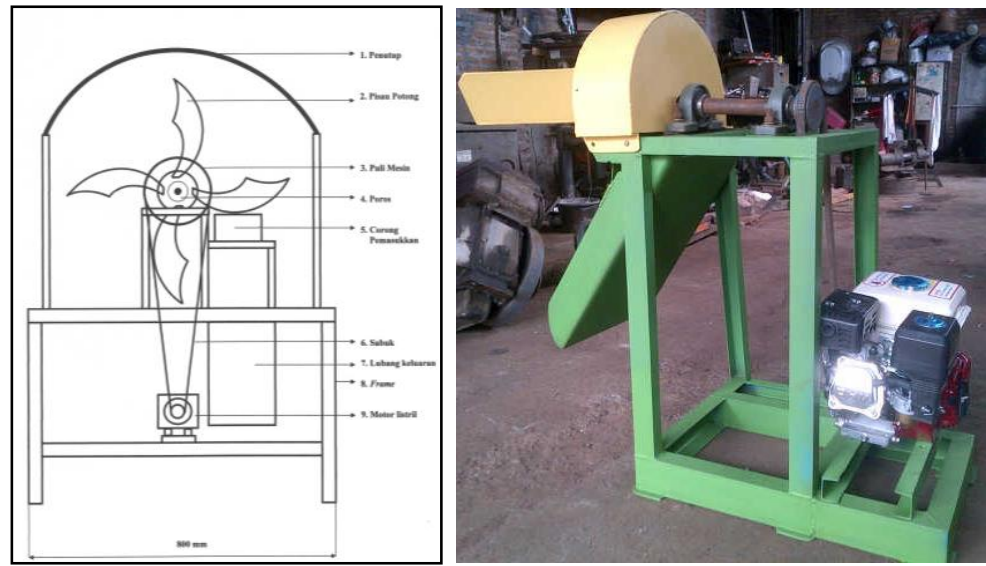

Gambar 4. Desain dan hasil jadi mesin perajang pakan ternak pisau 4 blade

Mesin perajang pakan ternak ini menggunakan daya engine 5,5 pk bensin dengan putaran motor $1450 \mathrm{Rpm}$. Jenis pisau perajangan menerapkan sistem 4 blade horisontal. Diameter lubang pemasukkan 200mm dan diameter hasil perajangan $150 \mathrm{~mm}$. Dimensi secara keseluruhan terdiri dari H:L:W = 1200:800:1000 mm. Mesin ini dioperasikan dengan mudah cukup menyalakan engine dan mengaturnya pada putaran iddle. Konstruksinya yang sederhana sehingga bisa dipindahkan ke berbagai tempat sesuai kebutuhan. Perawatan mesin ini relatif mudah karena menggunakan bahan yang dicat dengan lapisan tahan karat. Tingkat keselamatan kerja mesin ini relatif terjamin, karena posisi hopper masuk cukup ergonomis sesuai ketinggian standar manusia serta dilengkapi stopper sehingga aman terhadap tangan bagi operator.

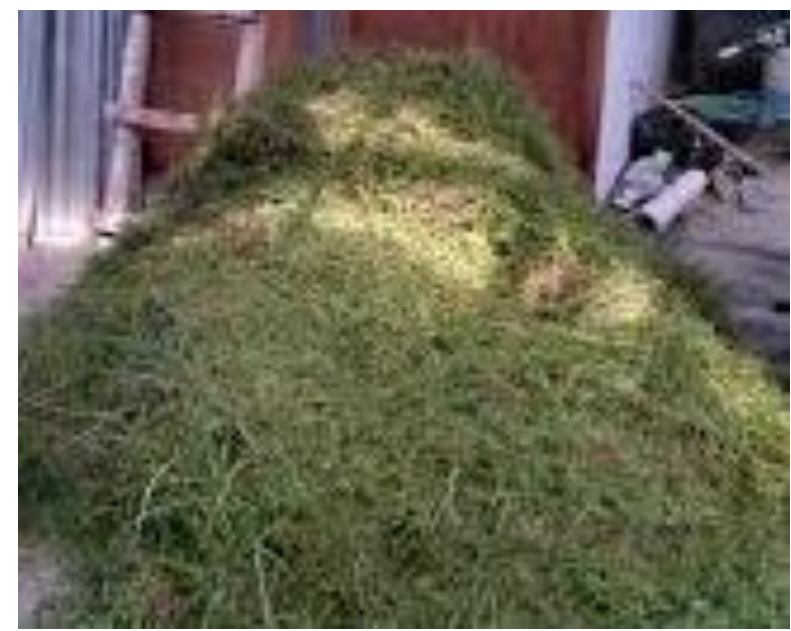

Gambar 5. Kualitas hasil perajangan rumput pakan ternak dengan mesin sistem 4 blade

Mesin ini mampu mencapai kapasitas produksi $650 \mathrm{~kg} / \mathrm{jam}$ dengan hasil ukuran homogen. Sehingga dengan adanya mesin tersebut UKM dapat meningkatkan dan menambah produktivitas kualitas sapi serta pendapatan pada UKM. Dengan rekayasa mesin ini bermanfaat mampu meringankan beban mitra dan mesin ini dapat dimanfaatkan kelompok yang lain sehingga akan meningkatkan pendapatan UKM.

Pembahasan mengenai hasil pengabdian terkait dengan hasil penelitian/pengabdian sebelumnya dapat dianalisis secara kritis sebagai berikut :

1. Rancang bangun mesin perajang rumput jerami yang ditulis oleh Purwono [3] tersebut lebih dititikberatkan kepada morfologi rumput jerami yang lebih kering 
dibandingkan rumput gajah pakan ternak yang kami kerjakan, sehingga kecepatan mesin harus terkendali $2000 \mathrm{rpm}$.

2. Rancang bangun mesin pencacah rumput gajah yang ditulis oleh Widdakso [4] tersebut menggunakan pisau lengkung yang mampu mencapai kapasitas produksi $110 \mathrm{~kg} / \mathrm{jam}$. Hasil kapasitas tersebut sedikit berbeda dengan yang kami kerjakan menggunakan pisau 4 blade mampu mencapai kapasitas $650 \mathrm{~kg} / \mathrm{jam}$.

3. Perancangan ulang mesin pencacah rumput dengan metode reverse engineering oleh Prasojo [5] tersebut mampu mencacah rumput dengan jumlah $100 \mathrm{~kg} / 10,73$ menit. Hasil kapasitas tersebut cukup optimal dibandingkan dengan mesin pencacah rumput pakan ternak yang kami buat. Hal tersebut dikarenakan hasil dari pengembangan sistem dobel pisau yang berbeda dengan kami yang hanya 1 pisau. Akan tetapi berdasarkan hasil ukuran perajangan menghasilkan relatif rerata sama panjang $0.5 \mathrm{~cm}$ yang homogen $90 \%$.

\section{KESIMPULAN}

Berdasarkan hasil dan analisa kegiatan pengabdian masyarakat terkait rangcang bangun mesin perajang rumput pakan ternak sapi diatas dapat diambil simpulan sebagai berikut :

1. Mesin peranjang rumput pakan ternak sapi ini berukuran 1200:800:1000 mm berpenggerak mesin bensin $5,5 \mathrm{pk}$ mampu mencapai kapasitas produksi 600 $\mathrm{kg} / \mathrm{jam}$.

2. Mesin perajang ini mampu meningkatkan kualitas perajangan rumput pakan ternak sapi dari $70 \mathrm{~kg} / \mathrm{jam}$ menjadi $600 \mathrm{~kg} / \mathrm{jam}$ dengan ukuran relatif homogen $90 \%$.

\section{UCAPAN TERIMA KASIH}

Penulis menyampaikan terima kasih kepada LPPM STTW Surakarta yang telah memberikan dukungan dalam terselesaikannya kegiatan ini secara lancar dan sistematis. Penulis juga mengucapkan terima kasih kepada semua civitas akademika dan pihak mitra binaan ukm ternak sapi di desa sedayu, jumantono, kabupaten karanganyar jawa tengah.

\section{DAFTAR PUSTAKA}

[1] S.L. Mujiyanti, dkk, Upaya Pemenuhan Kebutuhan Pakan Secara Berkelompok, Balai Pengkajian Teknologi Pertanian Jawa Barat, pp. 295-302, July 2015.

[2] B.H. Priyambodo, Suhartoyo, Rekayasa Mesin Perajang Pisau Ganda untuk Makanan Tambahan Ternak Sapi di Karanganyar, Senadimas Unisri, ISBN.978-60273158-5-3, pp. 24-27, September 2019.

[3] H. Purwono, dkk, Modifikasi Mesin Pencacah Jerami, Tugas Akhir Universitas Diponegoro Semarang, Maret 2013.

[4] I.Widdakso, dkk, Perancangan Alat Pencacah Rumput Gajah dengan Pisau Lengkung Kapasitas 110kg/jam, Jurnal Ilmiah Mahasiswa Universitas Muhammadiyah Ponorogo Komputek, 17 maret 2019.

[5] T.W. Prasojo, Perancangan Ulang Mesin Pencacah Rumput dengan Metode Reverse Engineering, S1 Teknik Mesin Universitas Muhammadiyah Surakarta, 31 Oktober 2016. 